\title{
ANALISA PERBANDINGAN HASIL PENGUJIAN LABORATORIUM DAN SIMULASI PADA BALOK BETON BERTULANG
}

\author{
Sudarno P Tampubolon ${ }^{1)}$ \\ 1) Teknik Sipil, Universitas Kristen Indonesia (UKI), Jakarta \\ darno_tampubolon@yahoo.com
}

\begin{abstract}
A reinforcement concrete beam behavior is substantial to design structure. Some failures can found in the beam because the beam reinforcement structure does not install like procedure design, this problem made failure for the structure. Knowing the behavior of the beam structure resulting from the load is necessary, as it can help to predict the strength of the structural beam and comfort of the structure being worked on. To find out and predict the strength and comfort of the structure reinforced concrete beam as a result of the load received is the experimental test and simulation. The simulation VecTor 2 was used to predict the shear force, crack, and displacement of the reinforced concrete beam when applied to the displacement load. This simulation considered the effect of the bond stress-slip effects of behavior reinforced concrete. Bonds stress-slip (0.139) gives a substantial influence on the strength and hysteretic response of the reinforced concrete beam. That is why this study considers the effect of the bond stress-slip on reinforced concrete. The results of the experiment test and simulations performed, the ratio of load capacity ranges from 1.00-1.095, and the crack pattern forms an angle of 45. All the results of simulation VecTor2 using the bond stress-slip effect would be compared with the result of the experimental test to see the behavior and accuracy of the simulation test.
\end{abstract}

Keywords: experiment test, reinforced concrete beam, simulation VecTor2, bond stressslip effect 


\begin{abstract}
ABSTRAK
Perilaku balok beton bertulang sangat penting dalam desain struktur. Beberapa kegagalan yang terjadi pada balok dikarenakan penulangan balok tidak terpasang seperti prosedur perencanaan/ desain, masalah ini dapat menimbulkan kegagalan pada struktur. Mengetahui perilaku struktur balok akibat beban yang diberikan dapat membantu memprediksi kekuatan balok struktural dan kenyamanan struktur yang direncanakan. Untuk mengetahui dan memprediksi kekuatan dan kenyamanan struktur balok beton bertulang akibat beban yang diterima maka dilakukan uji eksperimental dan simulasi. Simulasi VecTor2 digunakan untuk memprediksi gaya geser, retak, dan perpindahan pada balok beton bertulang saat diterapkan beban displacement. VecTor2 mempertimbangkan pengaruh/ efek ikatan antara tulangan longitudinal terhadap beton (bond stress-slip effect). Bond stress-slip effect (0.139) memberikan pengaruh yang cukup besar terhadap kekuatan dan respon histeris balok beton bertulang. Oleh karena itu penelitian ini juga mengkaji pengaruh dari tegangan efek bond-slip pada beton bertulang. Dari hasil pengujian dan simulasi yang dilakukan diperoleh rasio perbandingan untuk load capacity berkisar antara 1.00-1.095 dan pola retak membentuk sudut $45^{\circ}$. Seluruh hasil simulasi VecTor2 dengan menggunakan efek bond-slip akan dibandingkan dengan hasil pengujian eksperimen untuk melihat perilaku dan akurasi simulasi.
\end{abstract}

Kata kunci: uji eksperimental, balok beton bertulang, simulasi VecTor2, efek bond stressslip 


\section{PENDAHULUAN}

Gempa bumi yang terjadi mengakibatkan kerusakan dan kegagalan struktur pada bangunan tingkat tinggi dan bangunan tingkat rendah. Pada dasarnya kegagalan struktur terjadi ketika struktur mendapat/ memperoleh gaya yang menyerang struktur tersebut dan struktur tersebut tidak mampu mengatasi dan menahan beban/ gaya yang terjadi pada struktur tersebut, (Mo, 2002). Salah satu bagian struktur yang sering mengalami kegagalan/ kerusakan saat terjadi gempa adalah balok (beam), kegagalan ini umumnya terjadi akibat dari kurang diperhatikannya desain penulangan dengan baik, baik untuk desain tulangan utama (tulangan horizontal) maupun tulangan sengkang (stirrups) pada balok beton bertulang yang mengakibatkan balok tersebut mengalami kehancuran dan kerusakan (Altoontash, 2004). Itulah sebabnya perencanaan balok pada struktur bangunan haruslah dirancang dengan baik dan benar terutama dalam perencanaan penulangan baik untuk tulangan utama (tulangan horisontal) maupun penyaluran/ bengkokan pada tulangan sengkang (stirrups) serta desain beton yang digunakan harus sesuai dengan Standar Nasional Indonesia (SNI), sehingga nantinya struktur balok yang didesain/ direncanakan mampu meminimalis kerusakan dan kegagalan struktur.

Aspek lain yang perlu diperhatikan dalam perencanaan/ desain struktur adalah analisa perpindahan (displacement) yang terjadi pada balok, sehingga ketika struktur memperoleh gaya horizontal dan vertikal, bangunan dapat menahan gaya tersebut dan mencegah kerusakan dan kegagalan yang terjadi pada struktur bangunan tersebut dengan menggunakan penulangan yang baik dan benar. Untuk menyelidiki perilaku (kekuatan dan kegagalan) yang terjadi pada balok (beam) yang direncanakan/ desain maka perlu dilakukan simulasi dan pengujian terhadap balok tersebut. Untuk itu penggunaan software sangatlah penting dalam analisa maupun perencanaan saat ini. Software VecTor2/ simulasi VecTor2 merupakan salah satu software analisa finite elemen yang terperinci dengan akurasi yang cukup untuk axial load, gaya geser, retakan, dan deformasi yang bisa digunakan dalam memprediksi setiap perilaku balok beton bertulang pada daerah/ wilayah kritis di masa sekarang maupun masa yang akan datang.

VecTor2 merupakan salah satu software analisis struktur elemen hingga (finite element) yang bisa digunakan dalam memprediksi setiap perilaku struktur balok 
(beam) terhadap gaya geser, axial load, perpindahan, dan keruntuhan (retakan) (Wong, Vecchio, \& Trommels, 2013). Dalam penelitian ini, program elemen hingga nonlinear (VecTor2) digunakan untuk pemodelan/ studi kasus 3 (tiga) buah benda uji balok beton bertulang dari hasil pengujian laboratorium yang telah dilakukan. Balok beton bertulang yang dimodelkan dengan 2D nantinya dapat memperlihatkan lebih detail setiap perilaku dari tulangan yang digunakan baik untuk tulangan longitudinal maupun tulangan sengkang/ begel (hoops) dan keruntuhan yang terjadi pada beton yang digunakan, itulah sebabnya hasil dari uji eksperimental dan simulasi VecTor2 akan dibandingkan untuk dapat melihat setiap perilaku kegagalan dan kekuatan balok (Vecchio, Wong, \& Trommels, 2013).

\section{KAJIAN PUSTAKA}

VecTor2 adalah program analisis elemen hingga nonlinier (NLFEA) untuk analisis struktur membran beton bertulang dua dimensi (Vecchio et al., 2013). Jala halus elemen bertenaga rendah yang dibangun oleh model elemen hingga untuk VecTor2 dan metodologi ini memiliki keunggulan efisiensi komputasi, stabilitas numerik, dan cocok untuk struktur beton bertulang, yang membutuhkan jala (element) yang relatif halus untuk memodelkan detail perkuatan dan pola retak lokal.

Pengujian balok beton bertulang telah di uji oleh Shim dan Vecchio, 2004 di University of Toronto. Tes percobaan balok beton bertulang untuk dua belas spesimen di lakukan dengan ukuran dan parameter yang berbeda untuk menunjukkan perilaku balok saat diberikan beban. Perilaku untuk semua spesimen berbeda tergantung pada sifat material untuk beton, tulangan, dan panjang balok. Semua uji balok menggunakan penampang persegi panjang dengan kedalaman balok $552 \mathrm{~mm}$. Simulasi ini bertujuan untuk melihat perilaku balok (perpindahan dan pola retak) (Vecchio \& Shim, 2004).

Perilaku beton bertulang untuk retak, gaya geser, deformasi, tegangan, dan regangan dapat kita lihat dalam program analisis VecTor2 (Guner \& Vecchio, 2010). Perilaku ini sangat penting untuk diketahui terutama untuk balok (beam), sambungan balok kolom (beam-column joint), column (column) untuk mengetahui keamanan bangunan sebelum dilakukan pelaksanaan pembangunan struktur dilapangan, sehingga VecTor2 dapat digunakan di dalam memprediksi setiap kekuatan dan kegagalan struktur yang telah dilakukan pengujian eksperimen di 
laboratorium (Tampubolon, Wang, \& Wang, 2020).

Fokus utama dari penelitian ini adalah untuk memahami perilaku pengujian eksperimental dari 3 buah balok beton bertulang dan memodelkan dengan software VecTor2 dalam memprediksi kekuatan struktur di bawah pembebanan monotonik dan juga kondisi kontrol pemuatan pemindahan untuk balok beton bertulang sesuai dengan uji eksperimental yang dilakukan di laboratorium tanpa mengubah setiap parameter yang digunakan. Oleh karena itu, berbagai jenis koneksi, sifat material, dan detail koneksi yang diperiksa sangat penting untuk mengkonfirmasi penerapan program atau mengidentifikasi (Putri, 2016). Spesimen terdiri dari balok beton bertulang dengan ukuran $(80 \times 20 \times 20) \mathrm{cm},(100 \times 20 \times 20) \mathrm{cm}$, dan $(120 \times 20 \times 20) \mathrm{cm}$ yang dianalisis di bawah kontrol pemuatan perpindahan. Upaya pemodelan digunakan dengan menggunakan perilaku default atau opsi model konstitutif untuk membuktikan bahwa program berhasil menangkap parameter respons yang diperlukan tanpa modifikasi pada detail struktur.

Studi tentang perilaku bahan ikatan pada antarmuka antara tulangan dan beton (bonds stress-slip effect) merupakan salah satu bagian dari penelitian ini. Penelitian ini merumuskan "bagaimana menghitung gaya geser, perpindahan, dan prediksi retak yang terjadi pada balok beton bertulang saat diberikan beban dan kontrol pemuatan perpindahan. Untuk mengetahui perilaku struktur, penting untuk memprediksi beberapa kegagalan dan kekuatan dari pada struktur atau elemen strukturnya. Tujuan dari penelitian ini adalah untuk menunjukkan keberhasilan menggunakan software VecTor2 di dalam analisa perilaku pemodelan balok beton bertulang. Hasil dari penelitian ini akan memungkinkan VecTor2 digunakan sebagai alat pemodelan untuk mengetahui perilaku beton bertulang dan akan memberikan data yang berguna untuk perencanaan struktur (Sadeghian \& Vecchio, 2013). Sehingga kedepannya program VecTor2 akan digunakan untuk mendesain beberapa perilaku balok beton bertulang karena lebih mudah dan tidak mahal dibandingkan dengan studi eksperimental yang dilakukan di laboratorium, dan hasil dari simulasi VecTor2 juga dapat memberikan struktur data penilaian sebelum dan sesudah struktur di kerjakan di lapangan (Tsao, 2018; Tampubolon, 2020).

\subsection{Beton}

Umumnya pengujian untuk beton dilakukan pada spesimen silinder dan 
spesimen kubus. Kekuatan tekan diperoleh dari pengujian di laboratorium dengan beton yang digunakan adalah 28 hari. Kekuatan tekan dikenal sebagai kekuatan silinder $\left(\mathrm{f}^{\prime}{ }_{\mathrm{c}}\right)$ dan merupakan properti utama yang digunakan untuk tujuan desain. $\boldsymbol{\varepsilon}_{\mathrm{c}}^{\prime}$ adalah regangan tekan puncak beton yang tidak retak (Anonim, 2019). Untuk beton normal, Initial Tangent Modulus $\left(\mathrm{E}_{\mathrm{c}}\right)$ dapat dihitung dengan persamaan (Darwin, Nilson, \& Dolan, 2003):

$$
E_{c}=4730 \sqrt{f_{c}^{\prime}}\left(N / m^{2}\right)
$$

Tegangan tekan puncak beton retak, $\mathrm{f}_{\mathrm{p}}$ yang terjadi pada regangan puncak:

$$
\begin{aligned}
& \mathrm{f}_{\mathrm{p}}=\beta . \mathrm{f}_{\mathrm{c}}{ }^{\prime} \\
& \varepsilon_{\mathrm{p}}=\beta . \varepsilon_{\mathrm{c}}{ }^{\prime}
\end{aligned}
$$

Untuk menentukan kekuatan retak beton dan regangan retak dihitung dengan mengasumsikan hubungan linear-elastis sebelum retak dihitung dengan:

$$
\varepsilon_{\mathrm{cr}}=\frac{\mathrm{f}_{\mathrm{cr}}}{\mathrm{E}_{\mathrm{c}}}
$$

Ec adalah kekakuan tangen awal beton. Nilai $\left(f_{\mathrm{cr}}\right)$ dan $\left(\varepsilon_{\mathrm{cr}}\right)$ kemudian digunakan dalam respon teganganregangan dan model-model pengerasan tegangan. Kekuatan Tarik beton $\left(\mathrm{f}^{\prime} \mathrm{t}\right)$ diambil sebagai kekuatan retak beton uniaksial tertentu dengan:

$$
\mathrm{f}^{\prime}{ }_{\mathrm{t}}=\beta \cdot \sqrt{\mathrm{f}_{\mathrm{c}}^{\prime}}
$$

Tegangan silinder $\left(\mathrm{f}^{\prime} \mathrm{c}\right)$, regangan beton $\left(\varepsilon_{0}\right)$, berhubungan dengan nilai f'c, sebagai nilai positif pada regangan awal beton dapat di hitung dengan:

$$
\varepsilon_{0}=1.8+0.0075 \mathrm{f}_{\mathrm{c}}
$$

Untuk analisis VecTor2 material beton sangat penting dan harus mendapatkan data yang jelas. Perilaku analisis lebih jelas ketika penggunaan data selesai. Tabel 1 memberikan parameter beton yang digunakan untuk analisis balok beton bertulang. Beberapa parameter akan diperoleh dari tes percobaan dan parameter lainnya dapat dihitung (Sadeghian \& Vecchio, 2013).

Tabel 1. Material Properti Beton untuk Simulasi VecTor2

\begin{tabular}{lcc}
\hline \multicolumn{1}{c}{ Keterangan } & Simbol & Unit \\
\hline Nilai kekuatan tekan beton & $\mathrm{f}^{\prime}{ }_{\mathrm{c}}$ & $\mathrm{MPa}$ \\
Kuat tarik tulangan & $\mathrm{f}_{\mathrm{t}}$ & $\mathrm{MPa}$ \\
Modulus Elastisitas Beton & $\mathrm{E}_{\mathrm{c}}$ & $\mathrm{MPa}$ \\
Kekuatan tekan efektif beton & $\mathrm{f}_{\mathrm{c}}, \mathrm{eo}$ & $\mathrm{me}$ \\
Poisson rasio & $\mathrm{Mu}$ & - \\
Koefision muai panas & $\mathrm{C}_{\mathrm{c}}$ & $/{ }^{\circ} \mathrm{C}$ \\
Ukuran maksimum agregat & - & $\mathrm{mm}$ \\
Massa jenis & - & $\mathrm{Kg} / \mathrm{m}^{3}$ \\
Difusivitas termal & $\mathrm{K}_{\mathrm{c}}$ & $\mathrm{Mm}^{2} / \mathrm{s}$ \\
\hline
\end{tabular}




\subsection{Besi Beton/ Tulangan}

Besi Tulangan digolongkan sebagai besi polos dan ulir. Secara umum, diameter batang polos adalah $6,8,10,12,14,16$, 18, 20 dan $22 \mathrm{~mm}$, sedangkan diameter besi ulir adalah $6,8,10,12,13,14,16,18$, $18,20,22,25,29,32,36,43$ dan $57 \mathrm{~mm}$. Klasifikasi tulangan baja dengan diameter kecil dan besar ditunjukkan pada Tabel 2 di bawah ini:

Tabel 2. Material Properti Tulangan

\begin{tabular}{cccc}
\hline No. Tulangan & Berat per meter $(\mathrm{kg} / \mathrm{m})$ & Nominal Diameter $(\mathrm{mm})$ & Luas Tulangan $\left(\mathrm{mm}^{2}\right)$ \\
\hline 6 & 0.249 & 6.3 & 32.000 \\
10 & 0.561 & 9.525 & 71.968 \\
13 & 0.996 & 12.700 & 129.032 \\
16 & 1.556 & 15.875 & 200.000 \\
19 & 2.240 & 19.050 & 283.870 \\
22 & 3.049 & 22.225 & 387.096 \\
25 & 3.982 & 25.400 & 509.676 \\
29 & 5.071 & 28.651 & 645.160 \\
32 & 6.418 & 32.258 & 819.353 \\
36 & 7.924 & 35.814 & 1006.450 \\
43 & 11.410 & 43.002 & 1451.610 \\
57 & 20.284 & 57.328 & 2580.640 \\
\hline
\end{tabular}

\subsection{Bond Stress- Slip}

Menurut kode CEB (1993), sebagian besar didasarkan pada model Eligehausen, Popov, dan Bertero (1983) yang dijelaskan sebelumnya, parameter untuk beton terbatas berlaku setiap kali tekanan melintang $\mathrm{p} \geq 7.5 \mathrm{MPa}$ atau penguat melintang yang berjarak dekat (Sagbas, 2007). Nilai kuat tekan tulangan nol berhubungan dengan kasus kegagalan pemisahan yang tidak terbatas, sementara nilai kuat tekan tulangan 7.5 MPa sesuai dengan kasus kegagalan penarikan yang terbatas. Gambar 1. menunjukkan posisi rasio tulangan melintang untuk setiap jumlah lapisan palang posisi. Berdasarkan tekanan kurung yang diantisipasi, $\sigma$, faktor tekanan kurungan dapat dihitung sebagai berikut:

$$
\begin{aligned}
\beta & =\frac{\sigma}{7.5} \quad(\mathrm{MPa}) \quad 0 \leq \beta \leq 1 \ldots \ldots \\
\sigma & =\rho_{\mathrm{t}} \cdot \mathrm{f}_{\mathrm{y}} \ldots \ldots \ldots \ldots \ldots \ldots \ldots \ldots \ldots \ldots \ldots \ldots \ldots \ldots \ldots \ldots \ldots \ldots \ldots \ldots \ldots \ldots
\end{aligned}
$$

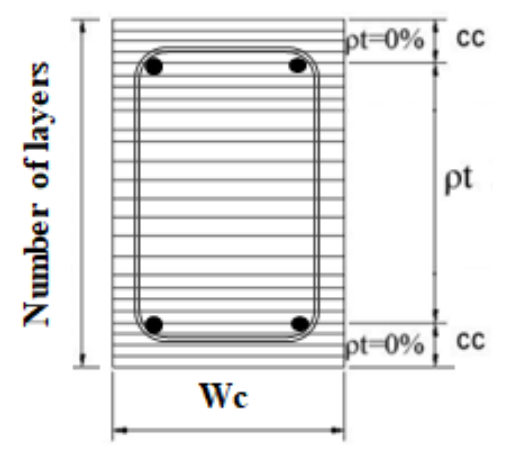

Gambar 1. Posisi Rasio Tulangan Melintang 


\section{METODE PERENCANAAN}

Adapun metode penelitian yang dilakukan adalah dengan melakukan uji eksperimental pada 3 buah balok beton bertulang dengan ukuran $(80 \times 20 \times 20) \mathrm{cm}$, $(100 \times 20 \times 20) \mathrm{cm}$, dan $(120 \times 20 \times 20) \mathrm{cm}$.

Gambar 2. Merupakan desain/ perencanaan tiga buah balok beton bertulang yang akan di uji. Selain itu Tabel 3. dan Tabel 4. merupakan penjelasan dari setiap parameter material desain (tulangan dan beton) yang di lakukan dalam pengujian balok beton bertulang. Kuat tekan beton (f'c) diperoleh dari pengujian 3 buah silinder beton dengan ukuran $(15 \times 30) \mathrm{cm}$. Dari hasil pengujian diperoleh nilai dari kuat tekan beton $34 \mathrm{MPa}$ dan nilai dari modulus elastisitas beton $\mathrm{E}_{\mathrm{c}}=4730 * \sqrt{\mathrm{f}_{\mathrm{c}}}$, $=4730 * \sqrt{34}=27581 \mathrm{MPa}$. Tabel 3. dan Tabel 4. menunjukkan detail parameter beton dan tulangan yang digunakan pada simulasi VecTor2.
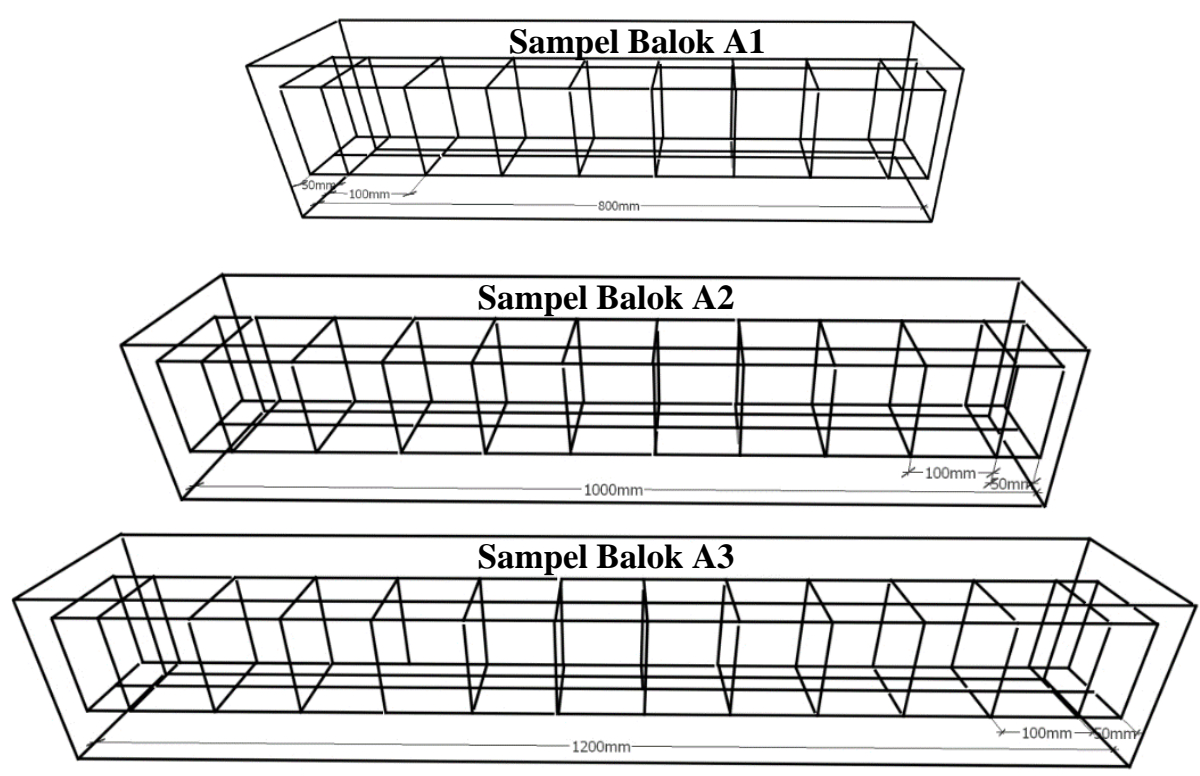

Gambar 2. Set-up Pengujian Balok Beton Bertulang

Tabel 3. Detail dan Parameter Tulangan pada Specimen Balok A1, A2, and A3

\begin{tabular}{ccccccccc}
\hline Type & $\begin{array}{c}\text { Diamter } \\
\text { Tulangan }\end{array}$ & $\begin{array}{c}\mathrm{d}_{\mathrm{b}} \\
(\mathrm{mm})\end{array}$ & $\begin{array}{c}\mathrm{A}_{\mathrm{b}} \\
\left(\mathrm{mm}^{2}\right)\end{array}$ & $\begin{array}{c}\mathrm{E}_{\mathrm{s}} \\
(\mathrm{MPa})\end{array}$ & $\begin{array}{c}\mathrm{f}_{\mathrm{y}} \\
(\mathrm{MPa})\end{array}$ & $\mathrm{E}_{\mathrm{sh}}(\mathrm{MP})$ & $\boldsymbol{\varepsilon}_{\mathrm{u}}\left(\mathrm{x10^{-3 } )}\right.$ & $\begin{array}{c}\mathrm{f}_{\mathrm{u}} \\
(\mathrm{MPa})\end{array}$ \\
\hline $\begin{array}{c}\text { A1, A2, } \\
\text { A3 }\end{array}$ & $\mathrm{D}-13$ & 12.7 & 126.61 & 200000 & 300 & 952 & 160 & 450 \\
\hline
\end{tabular}

Tabel 4. Detail dan Parameter Beton pada Specimen Balok A1, A2, and A3

\begin{tabular}{ccccccc}
\hline Specimen & $\begin{array}{c}\mathrm{E}_{\mathrm{c}} \\
(\mathrm{MPa})\end{array}$ & $\begin{array}{c}\mathrm{f}_{\mathrm{c}} \\
(\mathrm{MPa})\end{array}$ & $\mathrm{f}_{\mathrm{sp}}(\mathrm{MPa})$ & $\mathrm{f}_{\mathrm{t}}(\mathrm{MPa})$ & $\begin{array}{c}\text { Ukuran agregat } \\
(\mathrm{mm})\end{array}$ & $\boldsymbol{\varepsilon}_{\mathrm{o}}\left(\mathrm{x} 10^{-3}\right)$ \\
\hline $\mathrm{A} 1, \mathrm{~A} 2, \mathrm{~A} 3$ & 27581 & 34 & 2.37 & 1.568 & 40 & 16 \\
\hline
\end{tabular}




\section{HASIL DAN PEMBAHASAN}

Berikut ini akan di jelaskan hasil dari pengujian laboratorium dan simulasi VecTor2 pada pengujian balok beton bertulang A1, A2, dan A3.

\subsection{Pengujian Laboratorium}

Pada pengujian yang dilakukan pada 3 buah balok beton bertulang (balok A1, A2, dan A3) tujuannya adalah untuk melihat kondisi/ setiap perilaku keruntuhan (retak) dan nilai maksimum beban yang dapat di topang oleh balok beton bertulang. Pada saat pengujian balok beton bertulang, untuk sisi kiri dan kanan balok diberi perletakan sendi dan beban yang diberikan adalah beban perpindahan (displacement load) pada tengah-tengah balok yang akan di uji. Beban perpindahan yang diberikan pada setiap balok yang di uji, akan menunjukkan perilaku struktur yang terjadi pada balok tersebut. Gambar 3 menunjukkan pengujian pada balok beton bertulang A1, A2, dan A3.

Dari hasil pengujian yang dilakukan di laboratorium dapat diperoleh grafik hasil pengujian untuk 3 buah balok beton bertulang dengan ukuran $(80 \times 20 \times 20) \mathrm{cm}$, $(100 \times 20 \times 20) \mathrm{cm}$, dan $(120 \times 20 \times 20) \mathrm{cm}$. Gambar. 4 menunjukkan grafik hasil pengujian untuk 3 buah balok beton bertulang. Dari hasil pengujian yang telah dilakukan maka diperoleh nilai hasil kapasitas axial load pengujian untuk balok beton bertulang (Balok A1) adalah $425 \mathrm{kN}$, untuk Balok A2 diperoleh kapasitas axial load $375 \mathrm{kN}$, dan untuk Balok A3 diperoleh $400 \mathrm{kN}$.

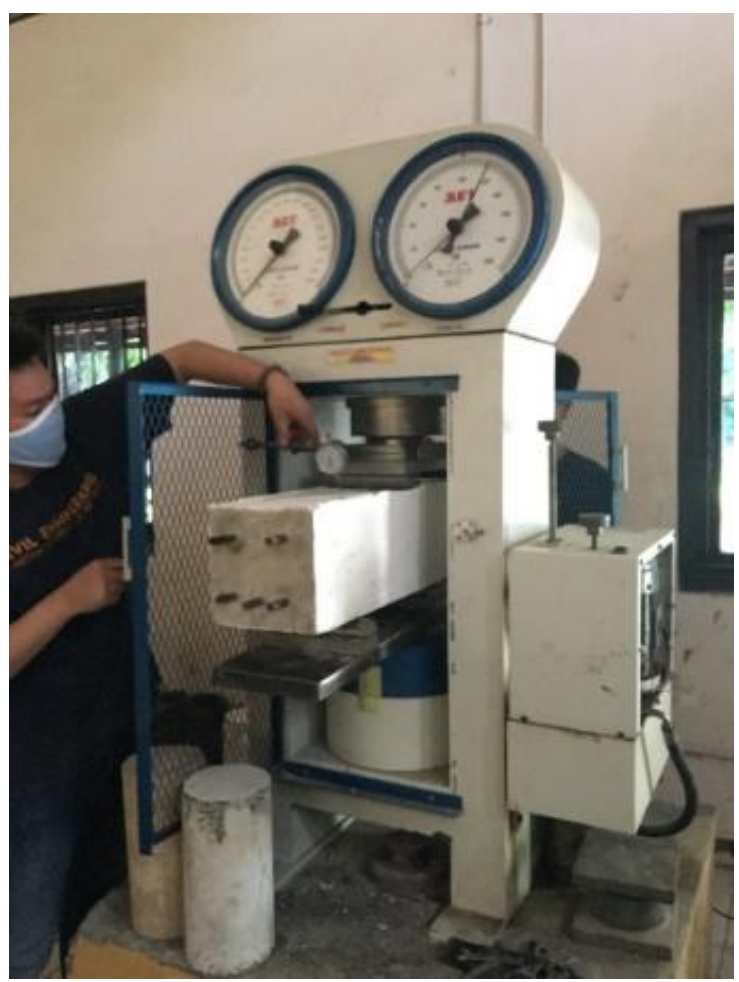
Gambar 3. Pengujian Balok Beton
Bertulang

Dari hasil pengujian yang dilakukan di laboratorium diperoleh juga gambar pola retak/keruntuhan yang terjadi pada balok beton bertulang. Gambar 5 . menunjukkan pola retak yang terjadi pada balok A1, A2, dan balok A3. Dari hasil pengujian diperoleh nilai deflection $1,5 \mathrm{~cm}$ untuk balok $\mathrm{A} 1$, deflection $2 \mathrm{~cm}$ untuk balok A2, dan deflection 1,6 cm untuk balok A3. 


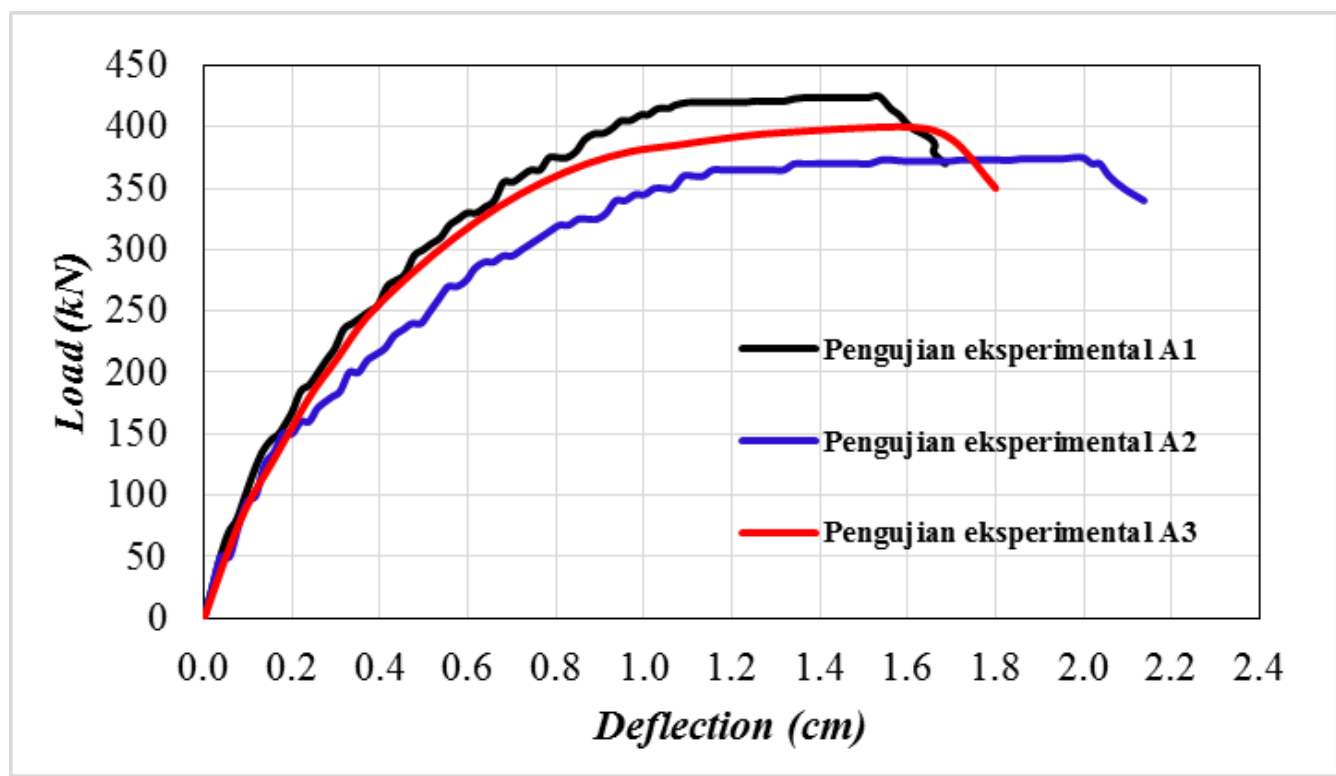

Gambar 4. Hasil Pengujian Balok Beton Bertulang untuk Balok A1, A2, dan A3
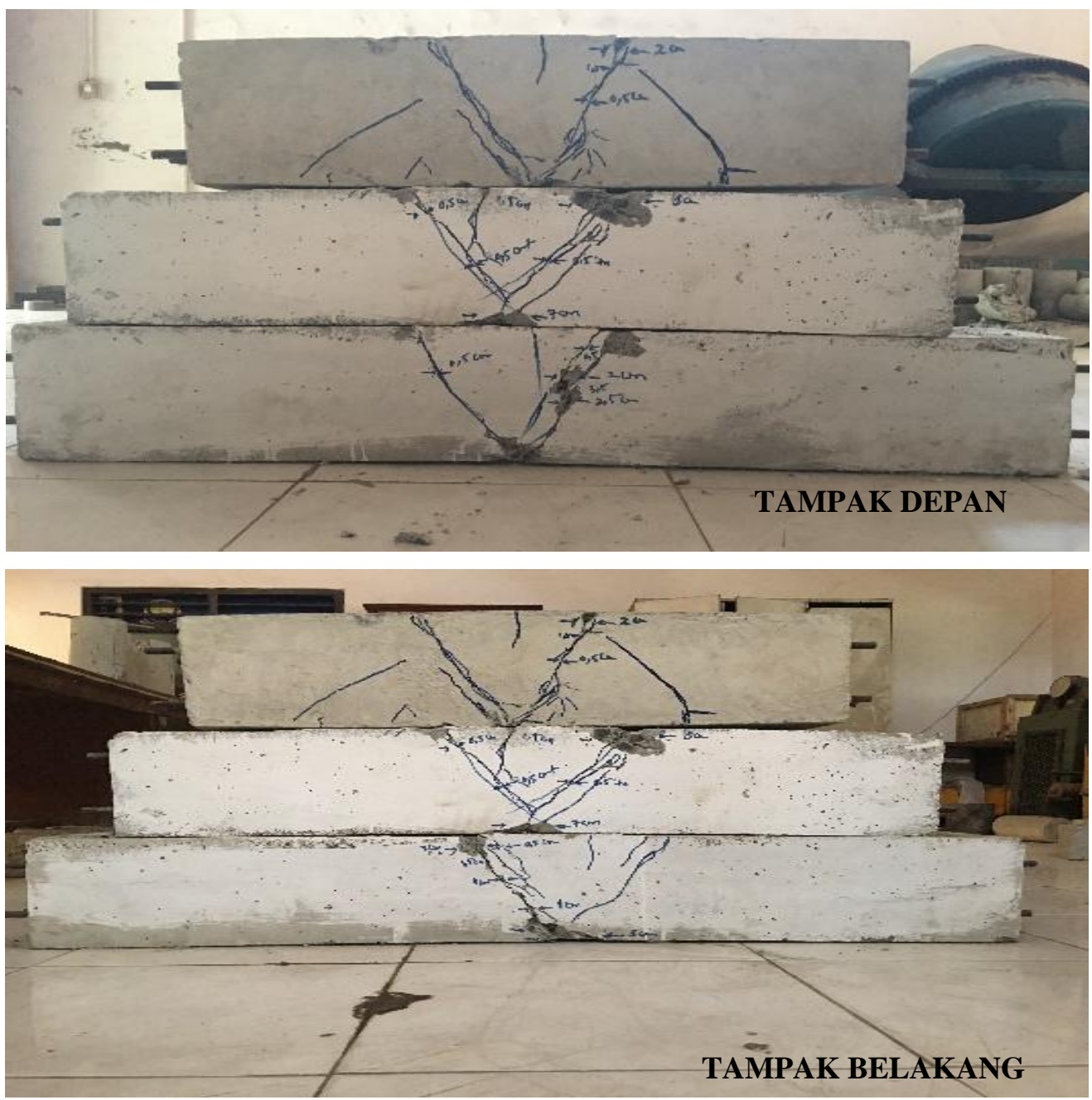

Gambar 5. Pola Retak pada Pengujian 3 Buah Balok Beton Bertulang 


\subsection{Perhitungan Bond-Slip}

Pada penelitian ini akan dilakukan perhitungan nilai dari bond-slip pada balok beton bertulang tipe A1, A2, dan A3. Berikut ini merupakan analisa perhitungan untuk mendapatkan nilai bond-slip:

$$
\begin{aligned}
\rho_{\mathrm{t}} & =\frac{2 \times \mathrm{Ab}}{\mathrm{st} \times \mathrm{wc}}=\frac{2 \times 32.2}{100 \times 200} \\
& =3.22 \times 10^{-3} \\
& =0.322 \% \\
\beta & =\frac{\sigma}{7.5} ;(\mathrm{MPa}) 0 \leq \beta \leq 1 \\
\sigma & =\rho_{\mathrm{t}} \times \mathrm{f}_{\mathrm{y}} \\
& =0.00322 \times 326 \\
& =1.0497 \mathrm{MPa} \\
\beta & =\frac{\sigma}{7.5}=\frac{1.04972}{7.5} \\
& =0.139
\end{aligned}
$$

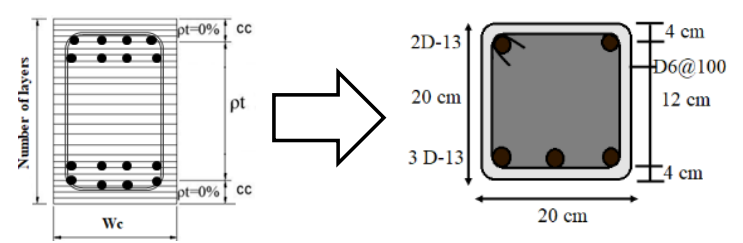

\section{Gambar 6. Detail Rasio Tulangan Melintang Balok}

\subsection{Simulasi VecTor2}

Untuk simulasi VecTor2 pada balok beton bertulang $\mathrm{A} 1, \mathrm{~A} 2$, dan $\mathrm{A} 3$ haruslah dilakukan terlebih dahulu penentuan wilayah (region) sesuai dengan dimensi pengujian laboratorium yang telah dilakukan Chak \& Vecchio (2013) dan Tampubolon, Wang, \& Wang (2018). Pada pengujian ini diperoleh data/ ukuran balok beton bertulang yang di uji adalah (80x20x20) cm, (100x20x20) cm, dan (120x20x20) cm. Gambar 7 merupakan gambar 2D wilayah/ region yang digunakan dalam simulasi VecTor2 pada balok A1, A2, dan A3. Pada simulasi VecTor2 untuk balok beton bertulang digunakan ukuran element $25 \mathrm{~mm}$, hal ini bertujuan untuk dapat melihat lebih detail pola retak/crack yang terjadi pada simulasi VecTor2.

Untuk simulasi VecTor2 pada balok beton bertulang $\mathrm{A} 1, \mathrm{~A} 2$, dan $\mathrm{A} 3$ sesudah menentukan wilayah (region) sesuai dengan dimensi pengujian laboratorium yang telah dilakukan, maka akan di lanjutkan dengan penentuan perletakan dan pembebanan. Untuk perletakan pada simulasi VecTor2 pada balok beton bertulang menggunakan perletakan sendi pada sebelah kiri dan perletakan rol pada sebelah kanan. Pembebanan yang di input adalah pembebanan displacement (load displacement) pada tengah-tengah balok beton bertulang. Gambar 8 merupakan simulasi VecTor2 pada balok A1, A2, dan A3 dengan menginput perletakan dan pembebanan displacement. 

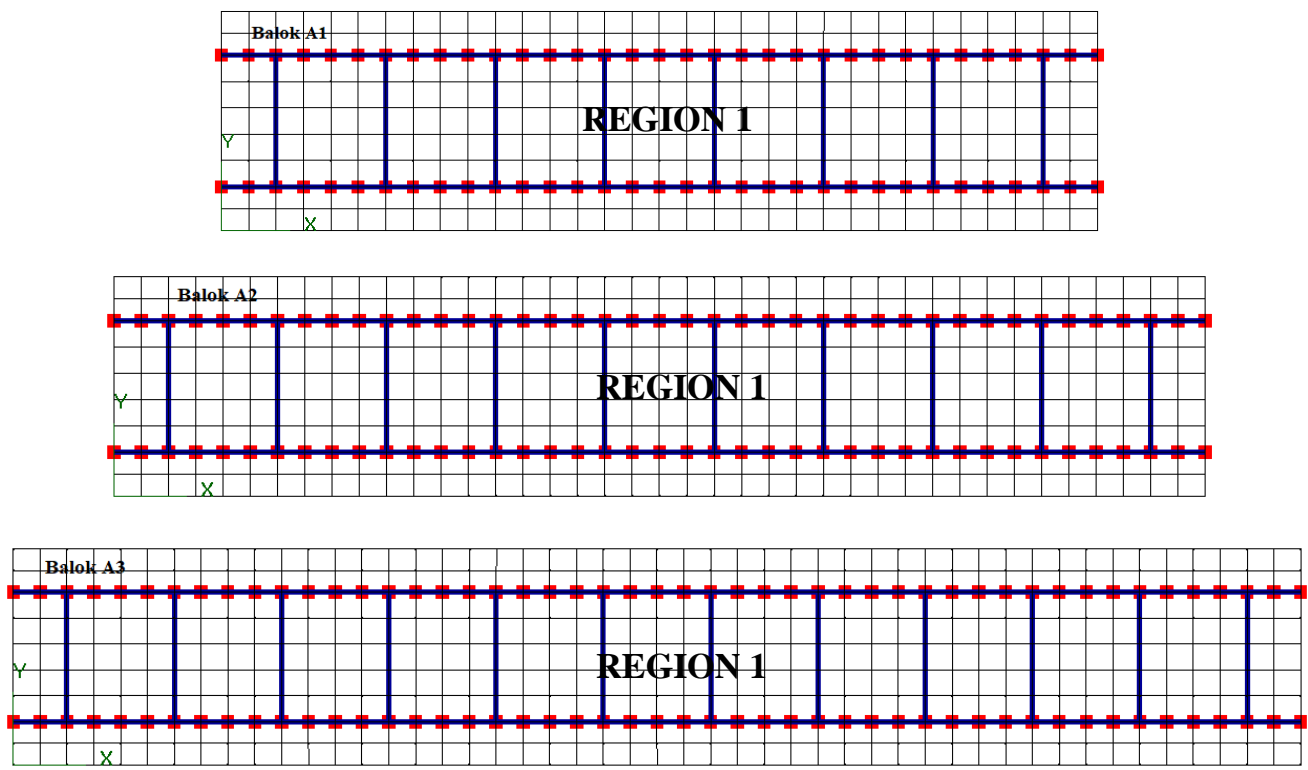

Gambar 7. 2D Wilayah/Region Simulasi Vector2 pada Balok Beton Bertulang dengan Jumlah Tulangan Tekan (Atas) 2D-13 dan Tulangan Tarik (Bawah) 3D-13
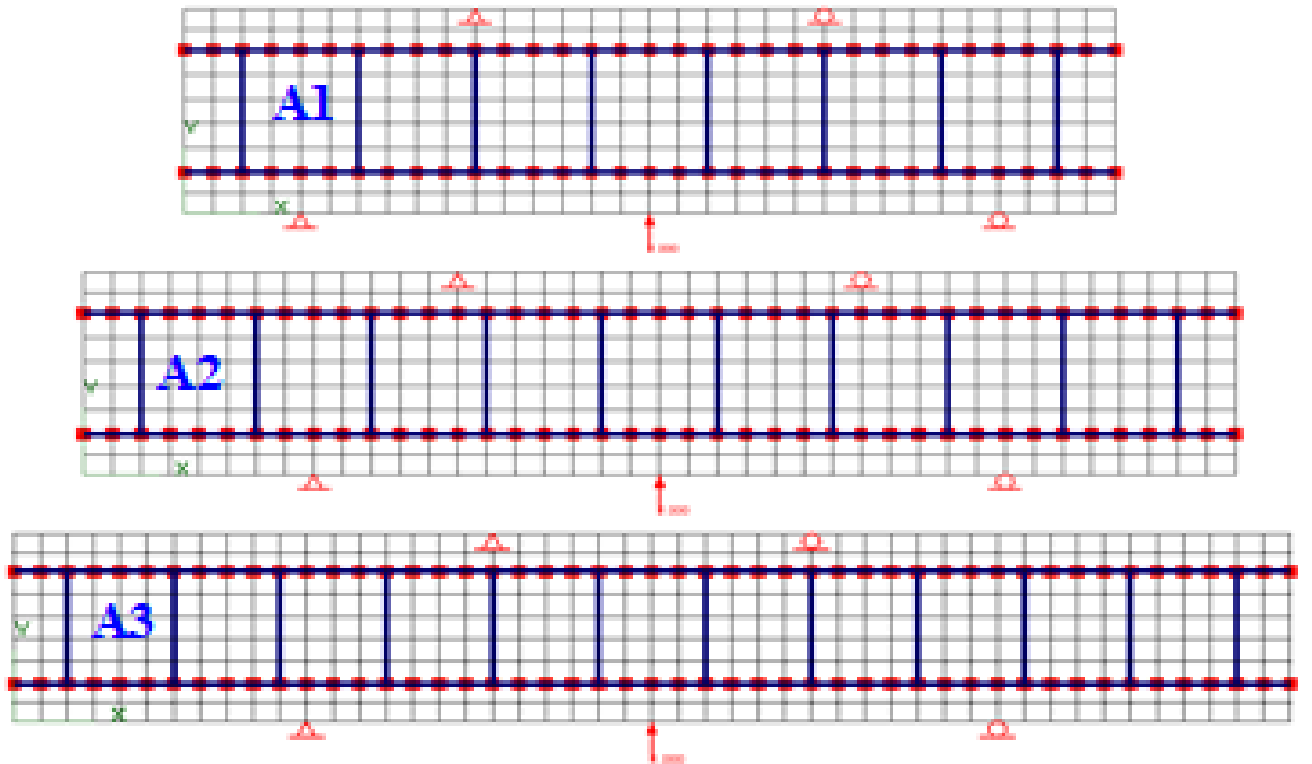

Gambar 8. Input Perletakan dan Pembebanan Simulasi VecTor2 pada Balok Beton Bertulang

Berikut merupakan hasil grafik pengujian simulasi VecTor2 untuk 3 buah balok beton bertulang dengan ukuran $(80 \times 20 \times 20) \mathrm{cm},(100 \times 20 \times 20) \mathrm{cm}$, dan (120x20x20) cm. Dari hasil pengujian yang telah dilakukan maka diperoleh hasil pengujian untuk balok beton bertulang
(Balok A1) nilai dari kapasitas axial load adalah $433 \mathrm{kN}$, untuk Balok A2 diperoleh kapasitas axial load $391 \mathrm{kN}$, dan untuk Balok A3 diperoleh kapasitas axial load 438 kN. Berikut ini merupakan grafik dari hasil pengujian balok beton bertulang untuk specimen A1, A2, dan A3. 


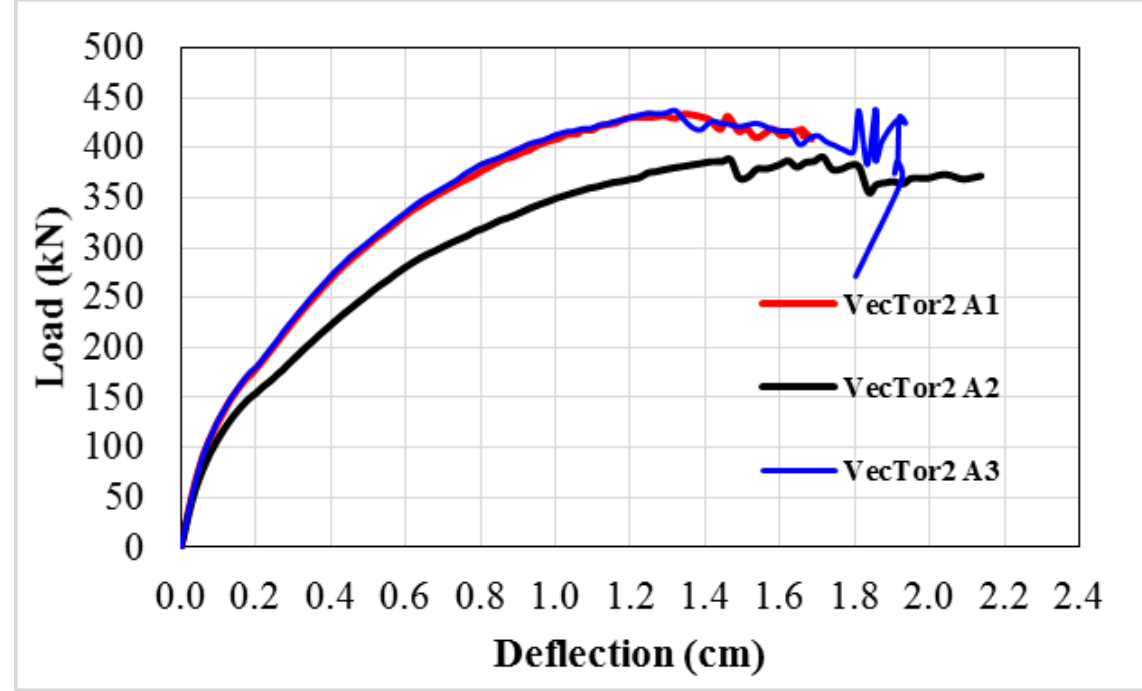

Gambar 9. Hubungan Beban vs Lendutan pada Simulasi VecTor2 Balok Beton Bertulang

Berikut merupakan hasil pengujian dan pola retak yang terjadi pada 3 buah balok beton bertulang dengan ukuran (80x20x20) cm, (100x20x20) cm, dan (120x20x20) $\mathrm{cm}$ dengan menggunakan Simulasi VecTor2. Pola keruntuhan dan retak yang terjadi hampir menyerupai dengan hasil pengujian laboratorium dan pola retak yang terjadi adalah pola retak diagonal akibat dari fungsi tulangan sengkang yang dipasang pada balok. Dari hasil simulasi VecTor2 diperoleh nilai deflection $1.4 \mathrm{~cm}$ untuk balok A1, deflection $1.72 \mathrm{~cm}$ untuk balok $\mathrm{A} 2$, dan deflection $1.855 \mathrm{~cm}$ untuk balok A3.
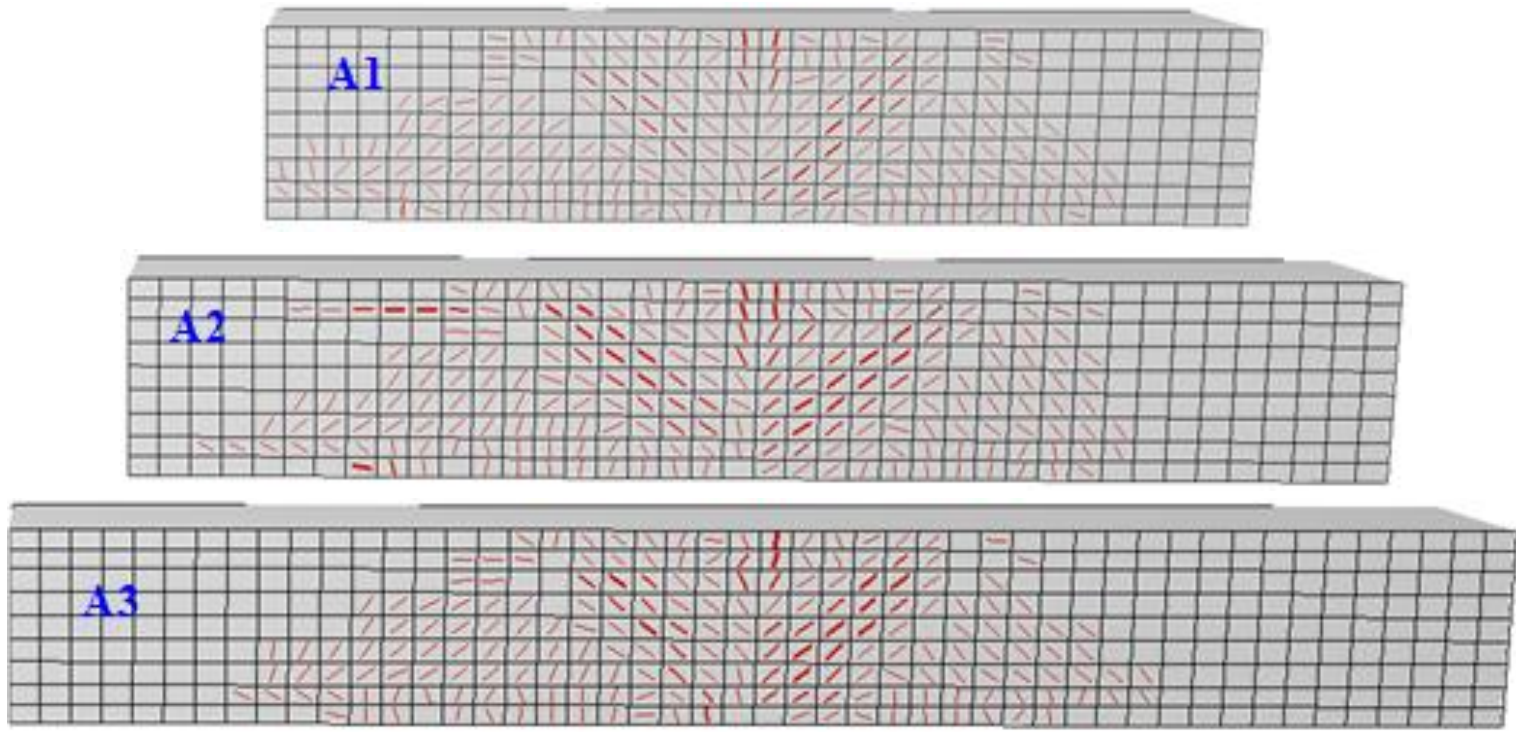

Gambar 10. Pola Retak pada Pengujian 3 Buah Balok Beton Bertulang dengan Simulasi VecTor2 


\subsection{Perbandingan Hasil Pengujian Laboratorium dan Hasil Simulasi VecTor2}

Dari hasil pengujian laboratorium dan simulasi VecTor2 maka diperoleh nilai dari hasil pengujian seperti pada Gambar. 11 dan Tabel 5. Nilai dari pada rasio perbandingan antara simulasi VecTor2 dan pengujian eksperimental digunakan untuk melihat keakuratan nilai dari pada simulasi yang digunakan, dimana nilai rasio perbandingan diperoleh 1.019-1.095 dari hasil perbandingan ini dapat kita lihat bahwa simulasi VecTor2 dapat memprediksi perilaku yang terjadi pada pengujian eksperimental.

Tabel 5. Perbandingan Hasil Pengujian Laboratorium dengan Simulasi VecTor2

\begin{tabular}{|c|c|c|c|c|}
\hline Specimen & Deskripsi & $\begin{array}{c}\text { Uji } \\
\text { Eksperimental } \\
(\mathrm{kN})\end{array}$ & $\begin{array}{c}\text { Simulasi } \\
\text { VecTor2 } \\
(\mathrm{kN}) \\
\end{array}$ & Ratio \\
\hline (1) & (2) & (3) & (4) & $(4 / 5)$ \\
\hline \multirow[t]{3}{*}{ A1 } & Beban maksimum kapasitas balok $(\mathrm{Pu}), \mathrm{kN}$ & 425 & 433 & 1.019 \\
\hline & $\begin{array}{l}\text { Nilai defleksi pada pertengahan bentang balok } \\
\text { pada puncak beban }(\delta \mathrm{u}), \mathrm{cm}\end{array}$ & 1.5 & 1.4 & 0.93 \\
\hline & Nilai perhitungan bond slip & - & 0.139 & - \\
\hline \multirow[t]{3}{*}{ A 2} & Beban maksimum kapasitas balok $(\mathrm{Pu}), \mathrm{kN}$ & 375 & 391 & 1.043 \\
\hline & $\begin{array}{l}\text { Nilai defleksi pada pertengahan bentang balok } \\
\text { pada puncak beban }(\delta \mathrm{u}), \mathrm{cm}\end{array}$ & 2 & 1.72 & 0.86 \\
\hline & Nilai perhitungan bond slip & - & 0.139 & - \\
\hline \multirow[t]{3}{*}{ A3 } & Beban maksimum kapasitas balok $(\mathrm{Pu}), \mathrm{kN}$ & 400 & 438 & 1.095 \\
\hline & $\begin{array}{l}\text { Nilai defleksi pada pertengahan bentang balok } \\
\text { pada puncak beban }(\delta \mathrm{u}), \mathrm{cm}\end{array}$ & 1.6 & 1.855 & 1.16 \\
\hline & Nilai perhitungan bond slip & - & 0.139 & - \\
\hline
\end{tabular}

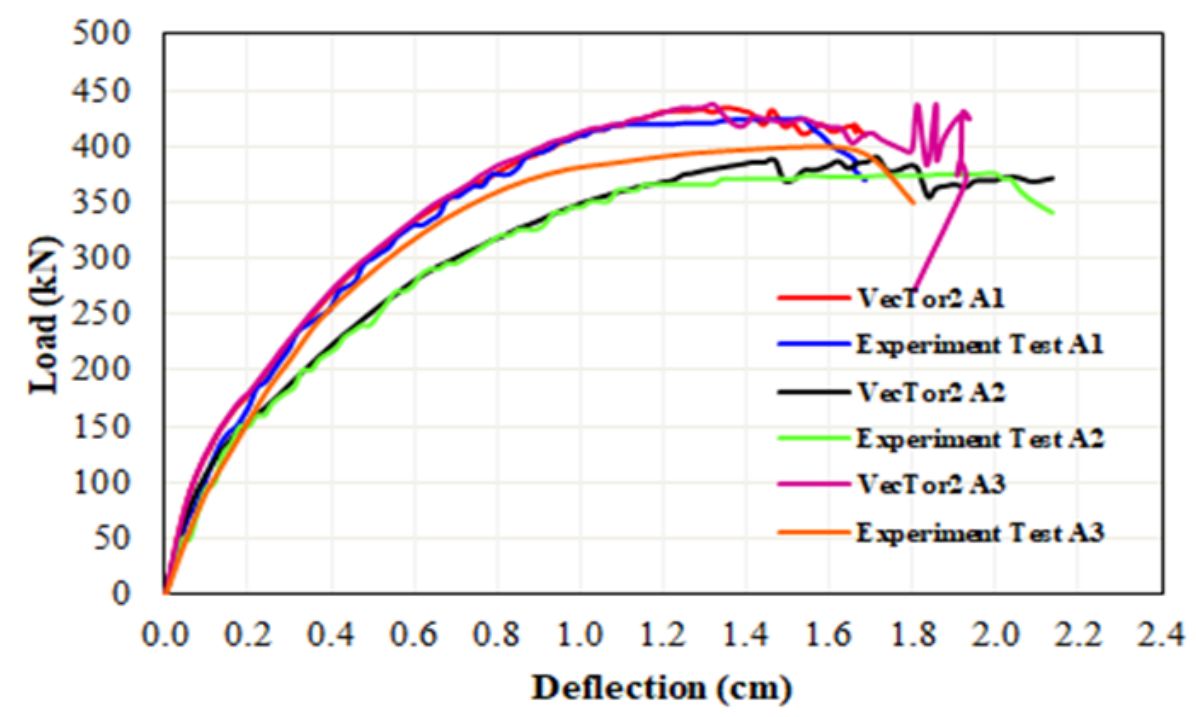

Gambar 11. Hysteretic Loop Kombinasi Pengujian Laboratorium dan Simulasi VecTor2 untuk Spesimen A1, A2, and A3 


\section{SIMPULAN}

Simulasi VecTor2 dan pengujian laboratorium untuk balok beton bertulang A1, A2, dan A3 memberikan beberapa kesimpulan dalam memprediksi setiap perilaku balok beton bertulang. Beberapa kesimpulan yang didapat dari pengujian eksperimen dan simulasi VecTor2 adalah sebagai berikut:

1. Penggunaan nilai bond stressslip (0.139) pada simulasi VecTor2 menunjukkan korelasi yang baik dengan hasil pengujian eksperimental untuk memperlihatkan perilaku (behavior) retak, perpindahan, dan beban maksimum pada balok beton bertulang.

2. Rasio tulangan melintang (tulangan utama) dan tulangan sengkang (stirrups) sangat mempengaruhi perhitungan nilai dari bond-stress slip.

3. Nilai gaya lateral tergantung dari kuat tarik tulangan dan kuat tekan tulangan, hal ini ditunjukkan dari setiap grafik histeristik pada pengujian laboratorium dan simulasi VecTor2.

4. Dari hasil pengujian eksperimental dan Simulasi
VecTor2 diperoleh nilai rasio perbandingan untuk beban kapasitas balok berkisar antara 1-1.095.

5. Analisa pola keruntuhan/retak yang terjadi pada simulasi VecTor2 dan pengujian eksperimental menunjukan pola retak yang sama dengan membentuk sudut $45^{\circ}$ (pola retak diagonal).

\section{DAFTAR PUSTAKA}

Altoontash, A. (2004). Simulation and damage models for performance assessment of reinforced concrete beam-column joints. PhD Thesis.

Anonim. (2019). SNI 03-2847-2019 tentang persyaratan beton struktural untuk bangunan gedung. Jakarta: Badan Standardisasi Nasional.

Chak, I., \& Vecchio, F. J. (2013). User's Manual of Janus. Retrieved from Online Publication website: http://www.civ.utoronto.ca/vector/us er_manuals/manual5.pdf

Darwin, D., Nilson, A., \& Dolan, C. (2003). Design of Concrete Structures, Thirteenth Edition. New York.

Guner, S., \& Vecchio, F. J. (2010). Pushover analysis of shear-critical frames: Formulation. ACI Structural Journal. https://doi.org/10.14359/51663389

Mo, Y. L. (2002). Reinforced concrete structures. In Earthquake Engineering Handbook. https://doi.org/10.1201/b19154-3 
Putri, L. F. (2016). Finite Element Analysis of Flexural Strengthening of Reinforced Concrete Beam by FRP. Master Thesis, Department of Civil Engineering, National Central University, Taiwan.

Sadeghian, V., \& Vecchio, F. J. (2013). Formworks-plus: Improved preprocessor for vector analysis software. Proceedings, Annual Conference - Canadian Society for Civil Engineering.

Tampubolon, S. P. (2020). Analisa Perilaku Balok Beton Bertulang dengan Menggunakan Simulasi VecTor2. Jurnal Rekayasa Konstruksi Mekanika Sipil, 3(2), 5564. https://doi.org/http://dx.doi.org/10.11 11/jrkms.v3i2.898

Tampubolon, S. P., Wang, C. Y., \& Wang, R. Z. (2018). Numerical Simulations of the bond stress-slip effect of reinforced concrete on the push over behaviour of wall. IJMERT Journal, 3(11), 39-45.

Tampubolon, S. P., Wang, C. Y., \& Wang, R. Z. (2020). Numerical simulations of the bond stress-slip effect of reinforced concrete on the push over behavior of interior beam-column joint. IOP Conference Series: Materials Science and Engineering. https://doi.org/10.1088/1757$899 X / 725 / 1 / 012028$

Tsao, J. J. (2018). Experimental Study on Failure Mode and Collapse Behavior of Reinforced Concrete Wall. Master Thesis, Department of Civil Engineering, National Taiwan University, Taiwan.

Vecchio, F. J., \& Shim, W. (2004). Experimental and Analytical Reexamination of Classic Concrete Beam Tests. Journal of Structural
Engineering, 130(3), 460-469. https://doi.org/10.1061/(ASCE)07339445(2004)130:3(460)

Vecchio, F. J., Wong, P., \& Trommels, H. (2013). Vector2 \& Formworks User's Manual. Second Edition. https://doi.org/10.1007/s0076900002 47

Wong, P. S., Vecchio, F. J., \& Trommels, H. (2013). VecTor2 \& Formworks User's Manual, Second Edition. In University of Toronto. 